Article

\title{
Capillary Barriers during Rainfall Events in Pyroclastic Deposits of the Vesuvian Area
}

\author{
Ciro Sepe ${ }^{1,2}$, Domenico Calcaterra ${ }^{1}$, Manuela Cecconi ${ }^{3, * \mathbb{D}}$, Diego Di Martire ${ }^{1} \mathbb{D}$, Lucia Pappalardo ${ }^{4}$, \\ Riccardo Scarfone $^{5,6}$, Enza Vitale ${ }^{1}$ (D) and Giacomo Russo ${ }^{1}$
}

1 Department of Earth Science, Environment and Resources, University of Napoli Federico II, 80126 Napoli, Italy; ciro.sepe@unina.it (C.S.); domcalca@unina.it (D.C.); diego.dimartire@unina.it (D.D.M.); enza.vitale@unina.it (E.V.); giarusso@unina.it (G.R.)

2 Department of Civil and Mechanical Engineering, University of Cassino and Southern Lazio, 03043 Cassino, Italy

3 Department of Engineering, University of Perugia, 06125 Perugia, Italy

4 INGV/Osservatorio Vesuviano-Napoli, 80125 Napoli, Italy; lucia.pappalardo@ingv.it

5 Geotechnical Consulting Group, London SW7 5BE, UK; riccardo.scarfone@glasgow.ac.uk

6 James Watt School of Engineering, University of Glasgow, Glasgow G12 8QQ, UK

* Correspondence: manuela.cecconi@unipg.it

Citation: Sepe, C.; Calcaterra, D.; Cecconi, M.; Di Martire, D.; Pappalardo, L.; Scarfone, R.; Vitale, E.; Russo, G. Capillary Barriers during Rainfall Events in Pyroclastic Deposits of the Vesuvian Area. Geosciences 2021, 11, 274. https://doi.org/10.3390/ geosciences 11070274

Academic Editors: Roberto Vassallo, Luca Comegna, Roberto Valentino and Jesus Martinez-Frias

Received: 12 May 2021

Accepted: 23 June 2021

Published: 29 June 2021

Publisher's Note: MDPI stays neutral with regard to jurisdictional claims in published maps and institutional affiliations.

Copyright: (c) 2021 by the authors. Licensee MDPI, Basel, Switzerland. This article is an open access article distributed under the terms and conditions of the Creative Commons Attribution (CC BY) license (https:/ / creativecommons.org/licenses/by/ $4.0 /)$.

\begin{abstract}
In the present paper, the capillary barrier formation at the interface between soil layers, which is characterized by textural discontinuities, has been analyzed. This mechanism has been investigated by means of a finite element model of a two-layer soil stratification. The two considered formations, belonging to the pyroclastic succession of the "Pomici di Base" Plinian eruption (22 ka, Santacroce et al., 2008) of the Somma-Vesuvius volcano, are affected by shallow instability phenomena likely caused by progressive saturation during the rainfall events. This mechanism could be compatible with the formation of capillary barriers at the interface between layers of different grain size distributions during infiltration. One-dimensional infiltration into the stratified soil was parametrically simulated considering rainfall events of increasing intensity and duration. The variations in the suction and degree of saturation over time allowed for the evaluation of stability variations in the layers, which were assumed as part of stratified unsaturated infinite slopes.
\end{abstract}

Keywords: pyroclastic soils; infiltration; capillary barriers; stability analysis

\section{Introduction}

Infiltration processes through layered soil deposits can be deeply affected by the presence of layers with contrasting hydraulic properties. In saturated conditions, the hydraulic conductivity of an upper, finer-grained layer overlying a coarser-grained layer can be higher than that of the coarser layer; however, in unsaturated conditions, the situation can be the opposite. The coarser layer can hinder the infiltration process through reduced unsaturated hydraulic conductivity, thus promoting the formation of a capillary barrier. This principle is applied in artificial layered soil covers to develop capillary barriers that prevent infiltration and promote lateral drainage (e.g., for landfill covers [1] and slope stabilization [2]).

Layered pyroclastic soil profiles are often complex, owing to the different eruptive phases and the deposition process of volcanic materials that follows. This is the case for the pyroclastic materials spread out over a large part of the mountainous areas surrounding the volcanic centers of Campania (southern Italy). Soil covers are indeed characterized by alternating layers of ashes, pumices, scoriae, and other volcanic products, which presents significant differences in terms of the geochemical nature, texture, density, hydraulic and mechanical properties [3,4].newpage Pyroclastic soil covers of Campania are frequently involved in rainfall-induced shallow landslides. Multiple factors can trigger landslides among these materials, including the site conditions (geomorphological characteristics, 
rainfall patterns, etc.) and properties (e.g., porosity, particle size distributions) of the pyroclastic soils [5-8].

The spatial variations in the textural characteristics and the related hydro-mechanical properties of the pyroclastic layers are the key factors controlling the rates of water infiltration, with the potential to form capillary barriers at the interface between layers of different soil textures (e.g., [1,9]). Capillary barriers have been considered by some authors to be one of the factors influencing the possible instability of shallow landslides $[10,11]$. Several studies [10-14] have shown that the differences in texture between the layers of the pyroclastic covers of Campania may affect infiltration processes and, eventually, slope instability.

The in situ observation of capillary barrier formation is a difficult task, due to the transient nature of the phenomenon and the fact that it is highly dependent on the initial soil-moisture profiles and boundary conditions, as shown by several laboratory experiments in soil columns, lysimeters, and instrumented flumes [15-19]. Numerical simulations represent an alternative to experimental measurements when examining the performance of the capillary barrier system. Oldenburg and Pruess [20] comprehensively studied the behavior of capillary barriers through the use of numerical methods. Stormont and Morris [21] and Khire et al. [1] performed parametric numerical analyses on horizontal capillary systems to investigate the effects of different parameters on the water storage capacity and hydraulic response of capillary barrier systems when subjected to different environmental loads. Numerical analyses were conducted by Rahardjo et al. [22] to determine the thickness and length of the fine- and coarse-grained materials of the capillary barrier system. Scarfone et al. $[23,24]$ used advanced numerical modeling to extensively study the effectiveness of capillary barrier systems in introducing water retention hysteresis into the hydraulic behavior of unsaturated soils, considering a new hydraulic conductivity model at a low degree of saturation, and the complex phenomenon of soil-atmosphere interaction in the long term.

In the present paper, the capillary barrier formation at the interface between soil layers, which is characterized by textural discontinuities, has been investigated by means of a finite element model. Two layers of soil stratification belonging to the pyroclastic succession of the "Pomici di Base" Plinian eruption (22 ka, Santacroce et al. [25]) of the Somma-Vesuvius volcano have been considered in the numerical model. The stratification is affected by shallow instability phenomena [26] that are likely caused by the progressive saturation during the rainfall events; this is a mechanism that is compatible with the formation of capillary barriers at the interface between layers of contrasting hydraulic properties during infiltration. The water retention properties and hydraulic conductivity function were derived for the two layers, and one-dimensional infiltration was parametrically simulated considering rainfall events of increasing intensity and duration. Variations in the suction and degree of saturation over time allowed for the evaluation of the stability of the stratification assumed as a stratified unsaturated infinite slope.

\section{Pyroclastic Soils}

The territory around the town of Palma Campania, about $20 \mathrm{~km}$ east of the city of Naples, Southern Italy, is located in the "Conca Napoletana" (Campanian plain) at the border of the Nola and Sarno plains; it is delimited to the East by the Apennine Mesozoic carbonate reliefs and to the West by the Somma-Vesuvius Quaternary volcanic complex (Figure 1). 


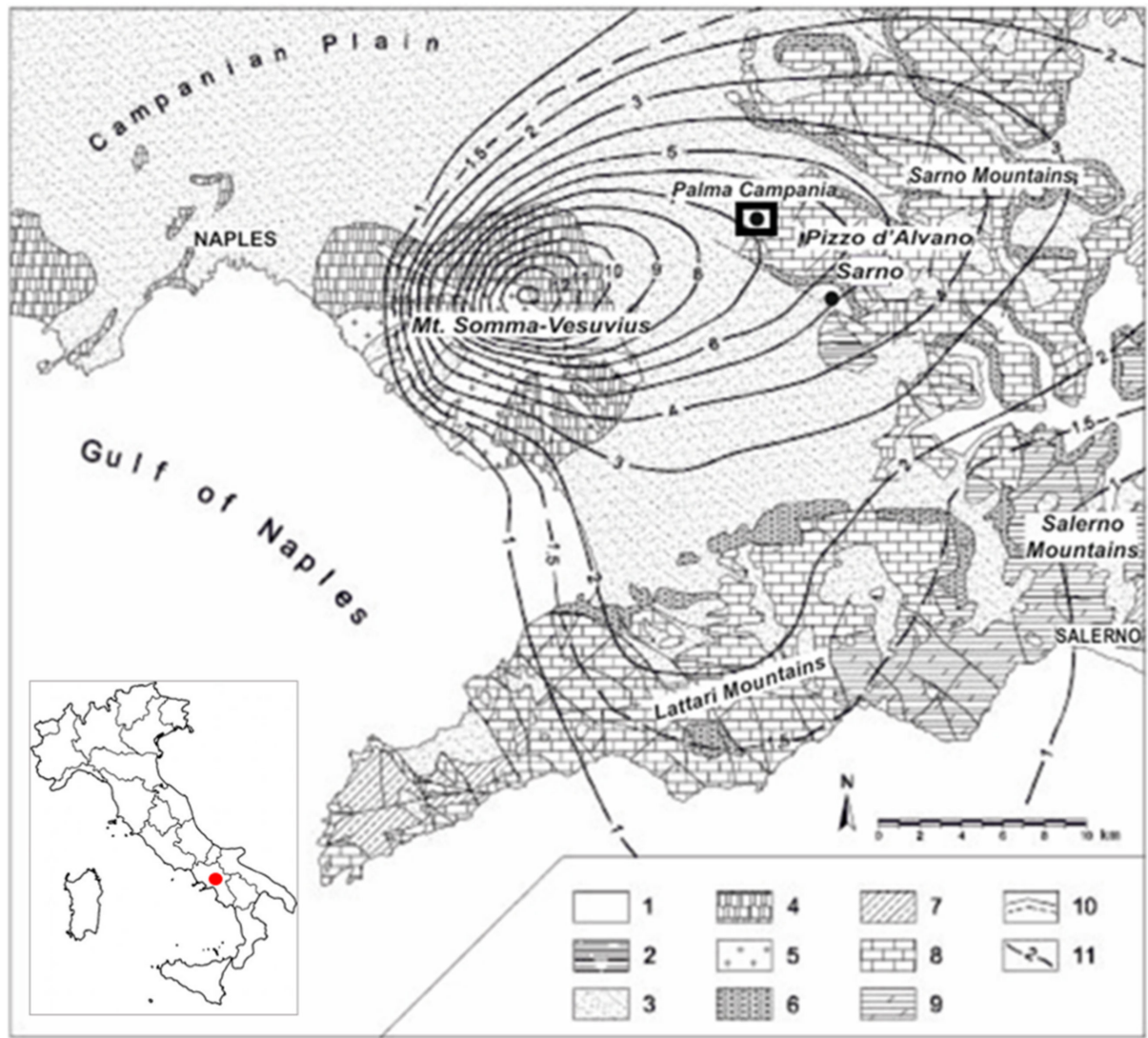

Figure 1. Geological map of the southwestern portion of the Campanian plain: (1) alluvial deposits, (2) travertine, (3) loose ash-fall deposits, (4) mainly coherent ash-flow deposits, (5) lavas, (6) debris and slope talus deposits, (7) Miocene flysch, (8) middle Jurassic-Upper Cretaceous limestones, (9) lower Triassic-Middle Jurassic dolomites and calcareous limestones, (10) fault, (11) total isopach lines (m) of the most important Mt. Somma-Vesuvius explosive eruptions. This figure is modified from [5].

On the carbonate slopes surrounding Palma Campania, relatively recent small landslides of the translational sliding type [27] have been observed among pyroclastic materials. A detailed field survey allowed for the identification of a series of recent landslides, mainly located in the "Vallone Lupici", involving the Somma-Vesuvius pyroclastic deposits. The failure surface has been identified at the interface between the grey pumice and dark scoria layers (Figure 2). This is possibly due, in large part, to the substantial variation in the grain size distributions and hydraulic properties between these two levels, such that water infiltration is affected. 


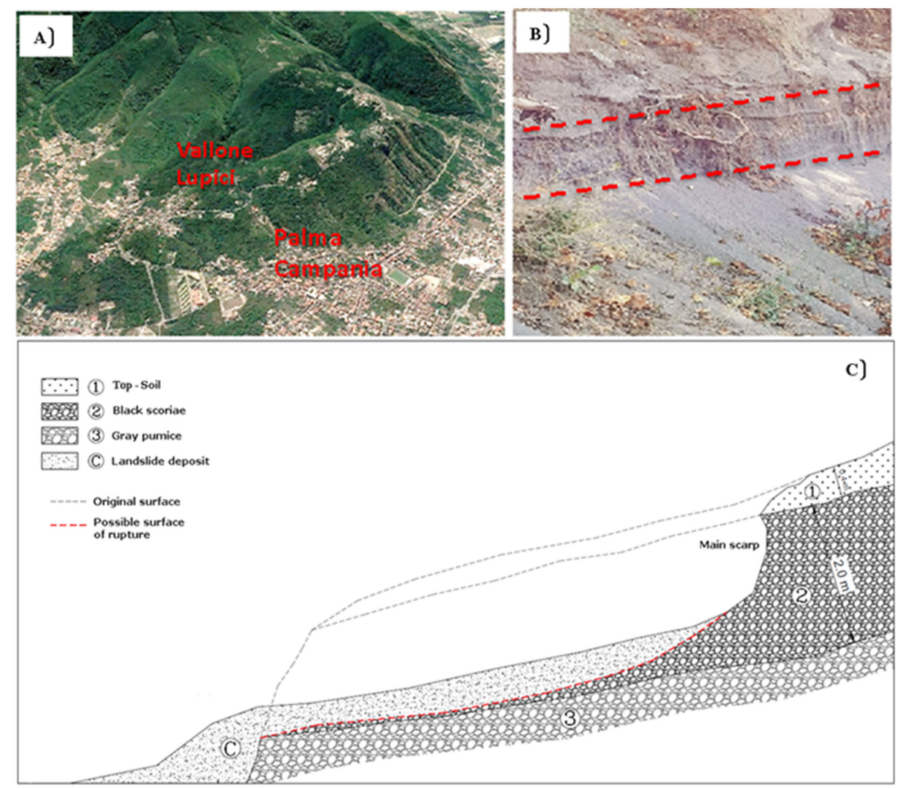

Figure 2. (A) A 3D satellite image of the studied area (from Google Earth); (B) the detachment zone of a landslide in Vallone Lupici; and (C) the cross-section of a typical landslide.

The studied volcanic succession (Figure 3) includes a few-meters-thick fallout deposit consisting — from the base to the top — of a basal, high-vesiculated, white pumice layer; an intermediate level of high to moderate vesiculated grey pumices; and an upper level of denser, black scoriae. This stratigraphic sequence corresponds to fallout deposits emplaced during the so-called "Pomici di Base" Plinian eruption (22,000 yrs BP [25]) of the SommaVesuvius volcano, which is well described in the literature [28-31].

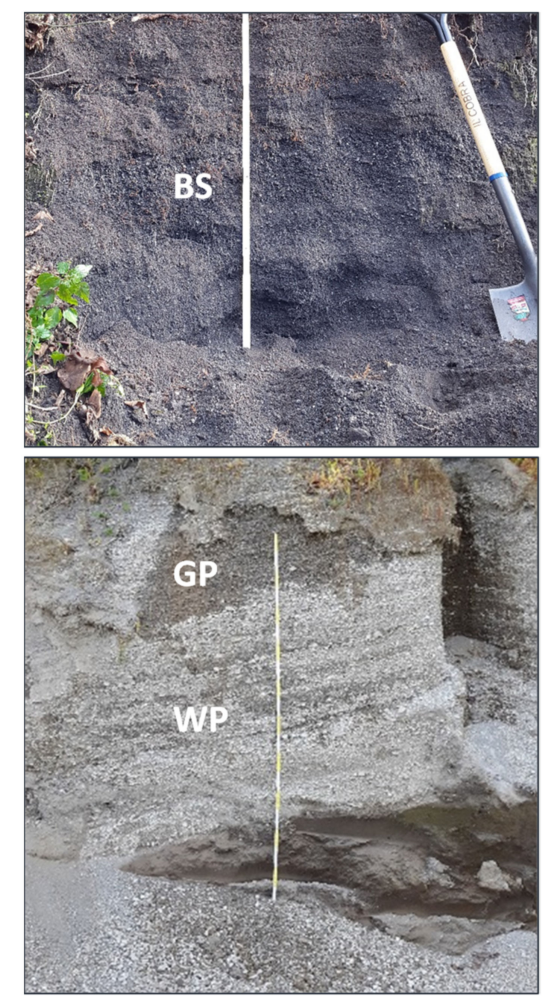

Figure 3. Vallone Lupici pyroclastic deposits—the identification of the Pomici di Base Plinian Eruption layers: BS, black scoriae; GPs, grey pumices; WPs, white pumices. 
The observed variations in lithological facies in the stratigraphy of this fallout deposit well-match the changes in eruption dynamics during the progression of the volcanic activity. In fact, the reduction in the clast vesicularity and size at the top of the sequence reflects the existence of a compositional gradient in the magma chamber. Whereas the first explosive phases tap the volatile-rich top of the felsic magma body (forming the first deposited materials at the base of the sequence), the following less-explosive phases sample partially degassed mafic magmas at the bottom of the reservoir (deposited later in the upper stratigraphic levels).

Bulk samples were collected at different stratigraphic heights, consistent with variations in lithological facies (i.e., grain size, color, and texture). Moreover, relatively undisturbed whole samples were retrieved using thin-walled tube samplers, from the zone close to the failure surface, specifically at the transition between the grey pumices and the black scoriae layer.

Grain size distributions of samples vary along the stratigraphic sequence. As reported in Figure 4-according to ASTM D422-black scoriae consist of $80 \%$ sand and $20 \%$ gravel, grey pumices consist of $80 \%$ gravel and $20 \%$ sand, and white pumices consist of $70 \%$ gravel and $30 \%$ sand.

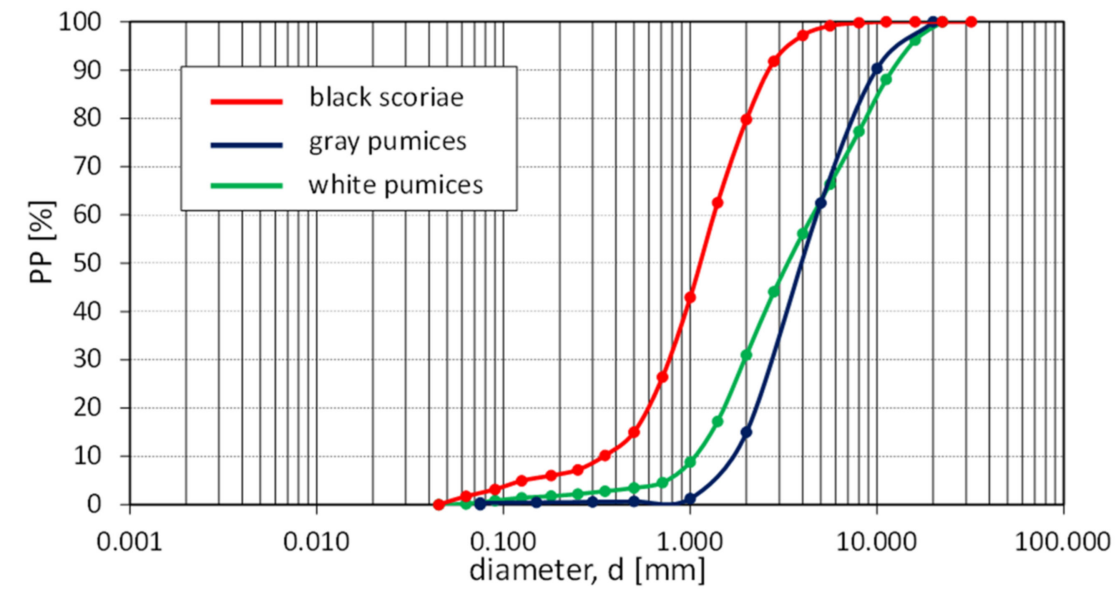

Figure 4. Grain size distributions of the investigated units in stratigraphic succession.

The specific weight of solid grains $\left(\gamma_{\mathrm{s}}\right)$ is $27.8 \mathrm{kN} / \mathrm{m}^{3}$ for black scoriae, $27.2 \mathrm{kN} / \mathrm{m}^{3}$ for grey pumices, and $24 \mathrm{kN} / \mathrm{m}^{3}$ for white pumices. Variations in the density of the solid phase are consistent with the geochemical changes described in the literature [29], from the dense trachybasaltic-latitic scoriae of the top layer to the light trachytic pumices at the bottom of the volcanic succession.

Bulk weight measurements, carried out on at least 100 single clasts of each representative class (namely $2 \mathrm{~mm}, 5 \mathrm{~mm}$, and $10 \mathrm{~mm}$ ), showed no significant variations within each stratigraphic unit [26]. The dry specific weight $\left(\gamma_{\mathrm{d}}\right)$ increased from the base to the top of the stratigraphic succession, with lower average values pertaining to basal white pumices $\left(\gamma_{\mathrm{d}}=6 \mathrm{kN} / \mathrm{m}^{3}\right)$, intermediate values pertaining to grey pumices $\left(\gamma_{\mathrm{d}}=12.4 \mathrm{kN} / \mathrm{m}^{3}\right)$, and larger values pertaining to black scoriae $\left(\gamma_{\mathrm{d}}=15 \mathrm{kN} / \mathrm{m}^{3}\right)$. Intergranular porosities, determined using a microstructural analysis performed by means of $X$-ray tomography on the reconstituted sample [26], were estimated to be equal to $33.8 \%$ for black scoriae and $36.5 \%$ for grey pumices.

\section{Water Retention Properties}

The water retention properties of the pyroclastic soil under study were determined using the model proposed by Arya and Paris [32], based on the particle size distribution of each formation in the stratigraphic sequence. In the model proposed by Arya and Paris, it is assumed that the solid grains are spherical, and the pore volume is approximated to that of 
cylindrical capillary tubes. For each $\mathrm{i}^{\text {th }}$ particle-size class, the pore radius $\left(\mathrm{r}_{\mathrm{i}}\right)$-associated with the mean grain radius $\left(R_{i}\right)$-is related to the suction value $s_{i}$ according to:

$$
r_{i}=R_{i}\left[2 e n_{i}{ }^{(1-\alpha)} / 3\right]^{1 / 2} \text { and } s_{i}=\frac{2 T_{w}}{r_{i}}
$$

where $n_{\mathrm{i}}, e, T_{\mathrm{w}}$, and $\alpha$ are, respectively, the number of spherical grains, the void ratio, the surface tension of water $\left(T_{\mathrm{w}}=7.27 \times 10^{-2} \mathrm{~N} / \mathrm{m}\right.$ at $\left.20^{\circ} \mathrm{C}\right)$, and a constant parameter larger than unity. Thus, for a given grain size distribution, Equation (1) allows for the calculation of the value of the suction required to desaturate a given fraction of pores. In the following, $\alpha$ is assumed to be constant, as consistent with the one evaluated for other typical pyroclastic weak rocks and the coarse-grained soils of Central Italy [33,34].

The Arya and Paris model was applied to two layers of the considered stratigraphic succession, namely to the black scoriae (BS) and grey pumices (GP), which form the interface of interest for the possible formation of a capillary barrier during an infiltration process. From the application of the method described above, volumetric water content values were obtained as a function of suction, which represents the behavior of the materials during wetting. These values were expressed in terms of the effective degree of saturation $\left(S_{e}\right)$, assuming a residual degree of saturation for both soils equal to zero, and were interpolated using the function proposed by Van Genuchten [35]:

$$
\mathrm{S}_{e}=\left[\frac{1}{1+(a s)^{n}}\right]^{m}
$$

where $a, n$, and $m$ are fitting parameters, reported in Table 1 for both GP and BS, along with fitting parameters proposed in the literature for similar coarse layers. Soil water retention curves for both the BS and GP layers are reported in Figure 5.

Table 1. Fitting parameters of the Van Genuchten model.

\begin{tabular}{cccccc}
\hline & \multicolumn{2}{c}{ This Study } & $\begin{array}{c}\text { Damiano } \\
\text { et al. (2012) }\end{array}$ & $\begin{array}{c}\text { De Vita et al. } \\
\mathbf{( 2 0 1 3 )}\end{array}$ & $\begin{array}{c}\text { Mancarella } \\
\text { et al. } \\
(\mathbf{2 0 1 2})\end{array}$ \\
\cline { 2 - 5 }$a\left[\mathrm{kPa}^{-1}\right]$ & BS & GP & 3.3 & 4.2 & 28 \\
\hline$n$ & 2.2 & 18.1 & 7 & 1.43 & 2.5 \\
\hline$m$ & 1.8 & 2.0 & 0.5 & 0.3 & 0.6 \\
\hline$S_{r}$ & 0.5 & 0.5 & 0.5 & 0 & 0 \\
\hline
\end{tabular}

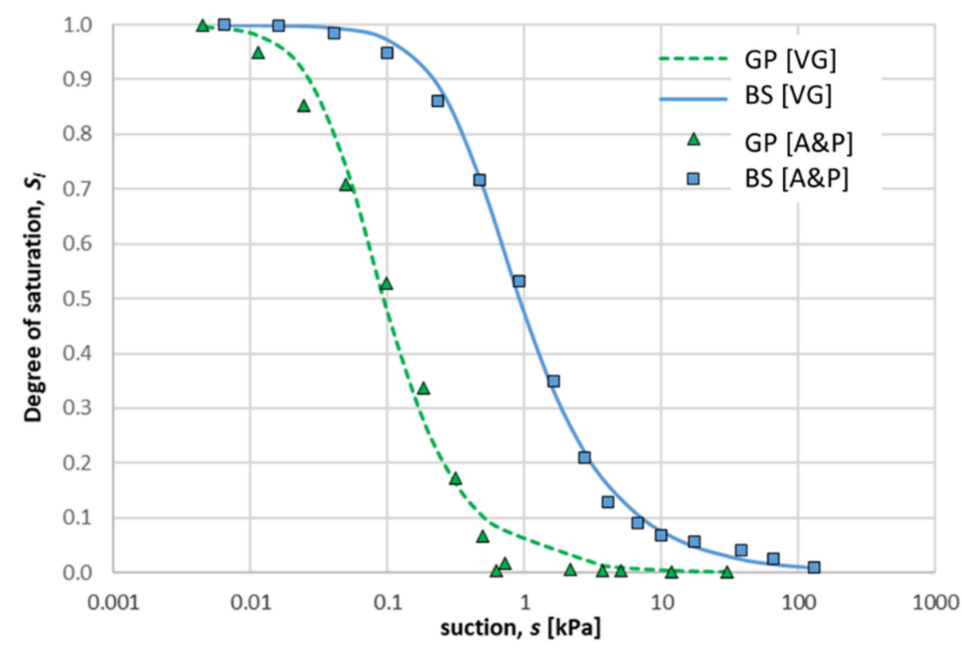

Figure 5. Water retention curves of GP and BS soils, estimated using the Arya and Paris (AP) model and the Van Genuchten (VG) model. 


\section{Infiltration Process}

The implemented numerical model, aimed at simulating the formation of a capillary barrier at the interface between two layers, is characterised by textural discontinuities. A parametric study of infiltration was carried out by varying the intensity and duration of the considered rainfall events.

The hydraulic constitutive Van Genuchten model for unsaturated soils was implemented in the CODE_BRIGHT finite-element code $[36,37]$. The numerical model was a vertical column of soil made of two layers: an upper layer, $2.5 \mathrm{~m}$ thick, representing the finer layer (BS) of a capillary barrier system, and a lower layer, $0.5 \mathrm{~m}$ thick, representing the coarser layer (GP) (Figure 6). The materials forming the two layers were each modeled by defining the soil water retention curve and the porosity. The intergranular porosities of reconstituted samples of BS and GP were assumed to be representative for each layer. The potential hydraulic effects of double porosity (i.e., intergranular and intragranular porosity) were not considered. Each of the two layers was treated as a uniform material. The hydraulic conductivity function was derived from the Mualem model [38].
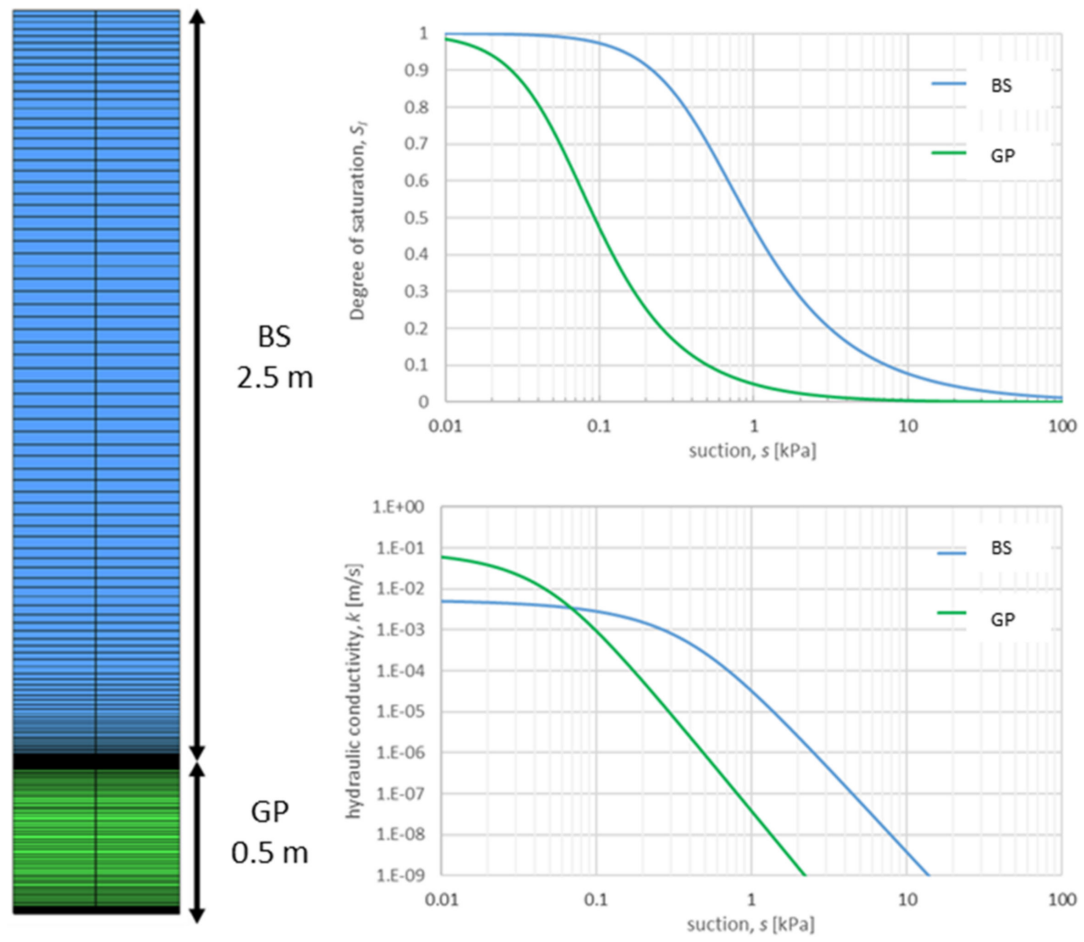

Figure 6. The geometry of the two-layer numerical model, Van Genuchten water retention curves, and Mualem hydraulic conductivity.

During numerical simulations of one-dimensional infiltration, only isothermal liquid transport was considered, with the solid phase treated as nondeformable and the gas phase as nonmobile. Thus, constant and uniform values of temperature $\left(\mathrm{T}=20^{\circ} \mathrm{C}\right)$, displacements of the solid phase $(\mathrm{u}=0 \mathrm{~m})$, and gas pressure $\left(\mathrm{u}_{\mathrm{a}}=0 \mathrm{kPa}\right)$ were imposed.

The initial condition for the numerical analyses was a hydrostatic suction profile with $s=20 \mathrm{kPa}$ at the bottom boundary, $s=50 \mathrm{kPa}$ at the top, and a linear variation between these values, with null water pressure at depth equal to $2.0 \mathrm{~m}$ below the bottom boundary $\left(z_{\mathrm{w}}=5 \mathrm{~m}\right.$ from the ground table). In this initial condition, the coarser layer was at a very low degree of saturation. For the bottom boundary condition, a free drainage condition was imposed. This consists of a zero water flow value if the suction is higher than $0.3 \mathrm{kPa}$, whereas a suction value of $0.3 \mathrm{kPa}$ is imposed if the suction at the bottom boundary attains this value. The value of $0.3 \mathrm{kPa}$ is the suction value at which the lower coarser layer GP starts draining water (see hydraulic properties in Figure 6). For the top boundary condition, 
a constant value of vertical water flux (the infiltration rate) was imposed. To assess the influence of the infiltration rate, different rainfall scenarios-in terms of rainfall intensity (5 $\mathrm{mm} / \mathrm{h}$ and $10 \mathrm{~mm} / \mathrm{h}$ ) and duration $(12 \mathrm{~h}$ and $24 \mathrm{~h}$ )—were considered. The selected rainfall events have been considered to be representative events at the site, as highlighted by the data shown in Figure 7, which was acquired across approximately two years of monitoring.

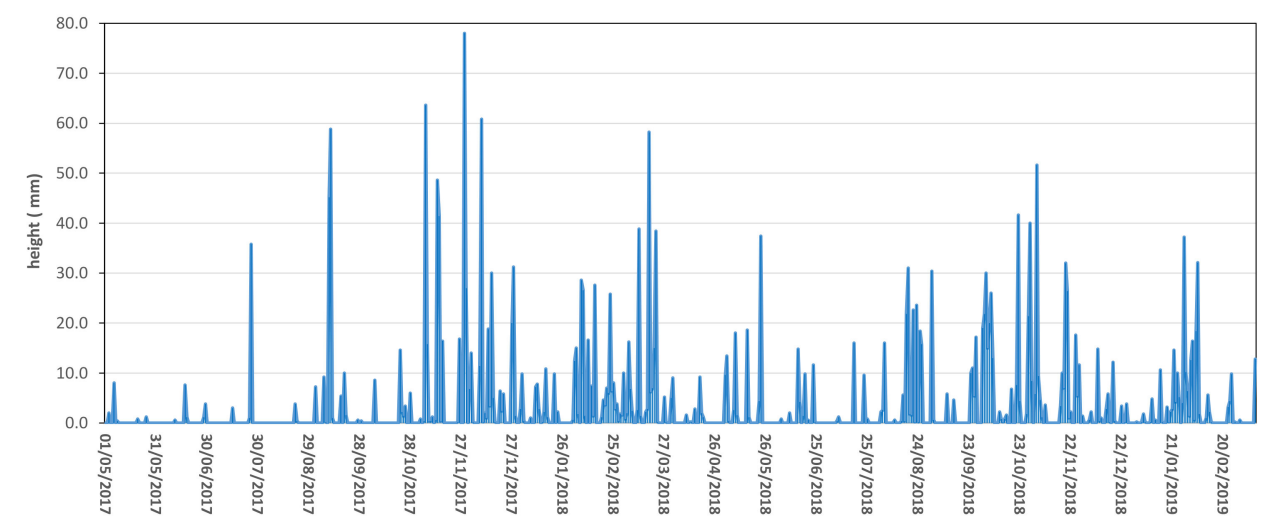

Figure 7. Rainfall events monitored at the site during the time interval from 05/2017-02/2019.

\section{Results and Discussion}

\subsection{Infiltration Process}

The infiltration analysis is carried out with reference to the suction and degree of saturation profiles, and by checking the water storage in the upper BS layer. These parameters are controlled over time, beginning at the start of the considered rainfall event.

For a rainfall event with an intensity of $5 \mathrm{~mm} / \mathrm{h}$ and a duration of $12 \mathrm{~h}$, it is observed that (Figure 8) the infiltration front proceeding downward causes a reduction in suction and an increase in the degree of saturation along the vertical column for periods of time that are longer than the duration of the rainfall event. When the interface is reached (depth of $2.5 \mathrm{~m}$ ), the degree of saturation increases and reaches its maximum value in the upper layer, while it remains almost constant in the lower layer. Similarly, suction decreases at the interface in the BS layer and reaches the minimum value, while it remains at the initial value in the grey pumices. The conditions described correspond with the formation of a capillary barrier at the interface between black scoriae and grey pumices. The capillary barrier also persists for a longer time, as evidenced by both the suction and saturation degree profiles at observation time $t=480 \mathrm{~h}$. Further confirmation of this permanence comes from the constant value over time of the water storage in the BS layer, as shown in Figure 9. 

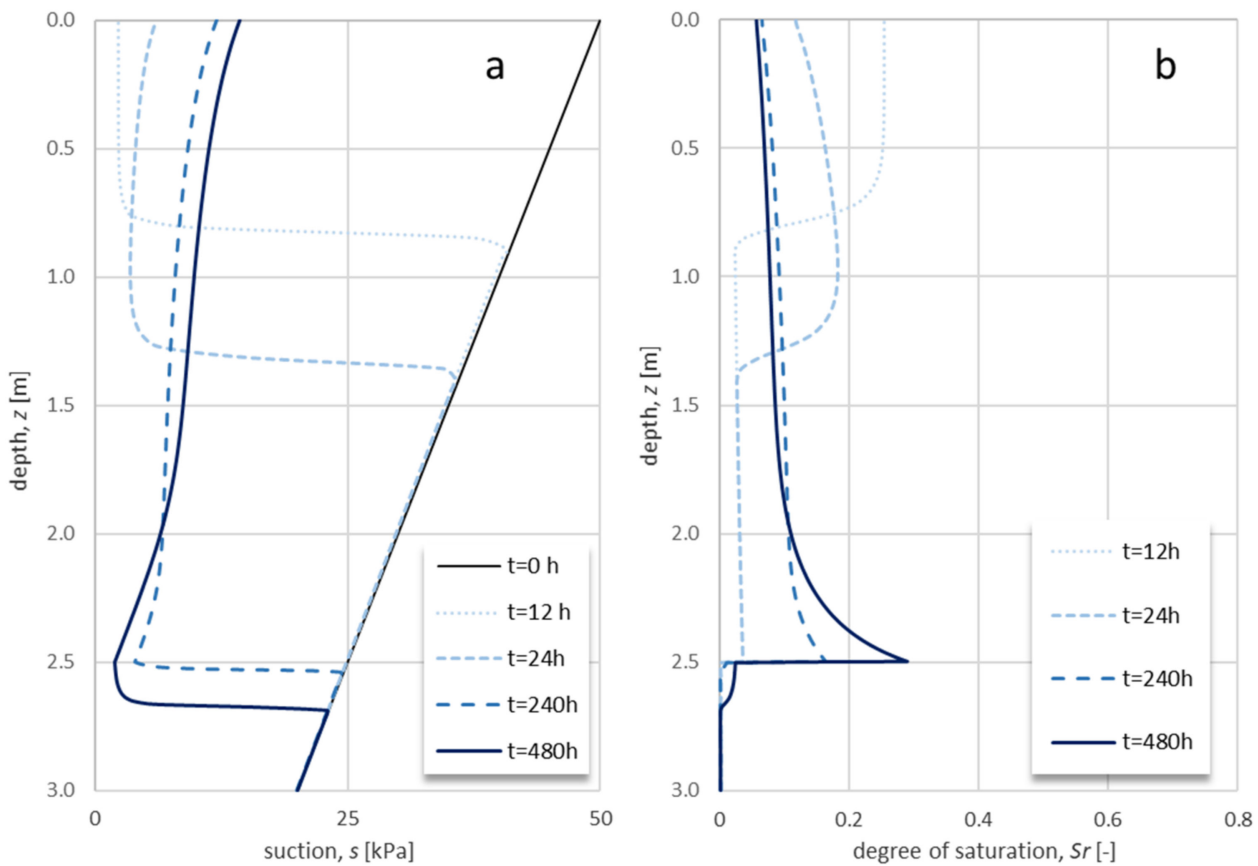

Figure 8. Infiltration process for a rainfall event with an intensity of $5 \mathrm{~mm} / \mathrm{h}$ and a duration of $12 \mathrm{~h}$ : (a) the suction profile, and (b) the degree of saturation profile.

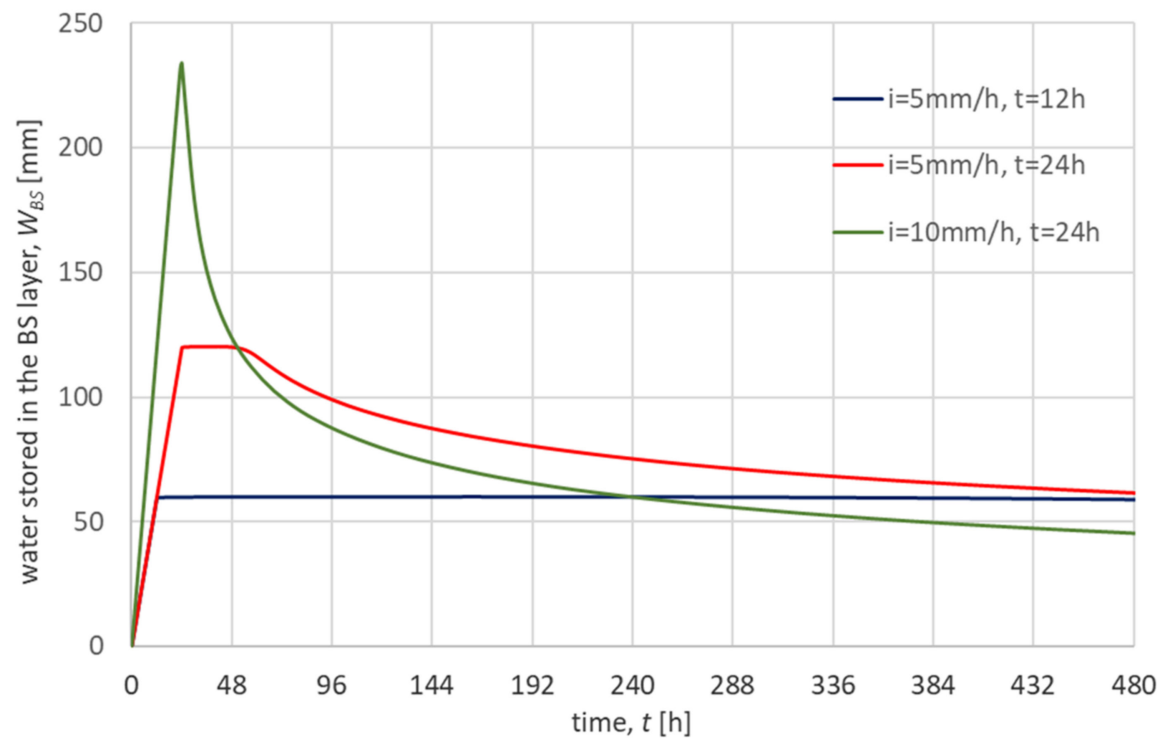

Figure 9. Water stored in the BS layer during the simulated infiltration processes.

For a rainfall event with an intensity of $5 \mathrm{~mm} / \mathrm{h}$ and a duration of $24 \mathrm{~h}$, the infiltration front close to the interface causes an increase in the degree of saturation (Figure 10a); however, this is coupled with suction reduction at the interface. The suction attained at the interface is so low that break-through has occurred in the capillary barrier, and water flow takes place toward the lower formation, with a progressive reduction in water storage in the upper black scoriae layer, as highlighted in Figure 9. As reported in Figure 11, break-through occurs when suction at the interface drops down from $25 \mathrm{kPa}$ to $0.6 \mathrm{kPa}$, which is close to the theoretical value $(\mathrm{s}=0.46 \mathrm{kPa})$ proposed by Lu and Likos [39]. 

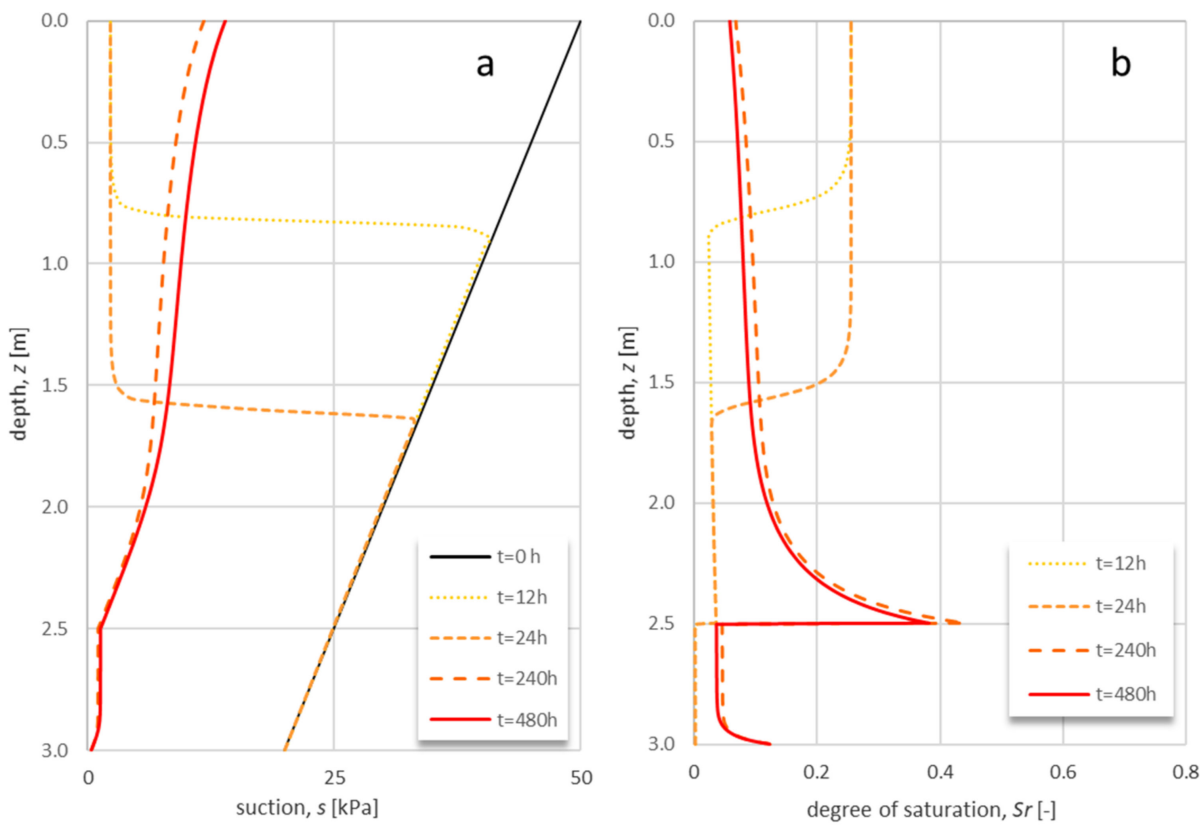

Figure 10. Infiltration process for a rainfall event with an intensity of $5 \mathrm{~mm} / \mathrm{h}$ and a duration of $24 \mathrm{~h}$ : (a) the suction profile, and (b) the degree of saturation profile.

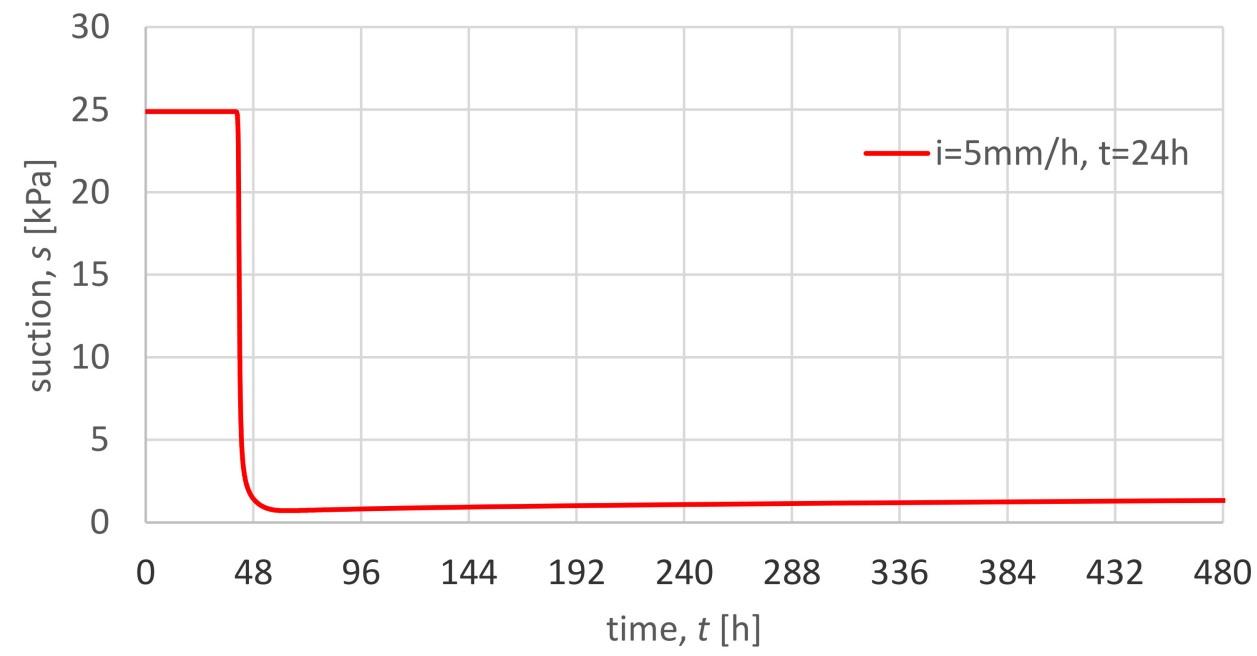

Figure 11. Suction evolution at the interface between BS and GP during the rainfall event at an intensity of $5 \mathrm{~mm} / \mathrm{h}$ and a duration of $24 \mathrm{~h}$.

For a rainfall event with an intensity of $10 \mathrm{~mm} / \mathrm{h}$ and a duration of $24 \mathrm{~h}$ (Figure 12), the infiltration front crosses the interface in less time than the duration of the rainfall event. The observed increase in the degree of saturation in the BS layer approaching the interface is due to the contrast in the hydraulic conductivities of the two layers. The reduction in water storage over time, beginning at the end of the rainfall event, is a further confirmation that the capillary barrier effect at the interface is rapidly lost for the simulated rainfall event. 

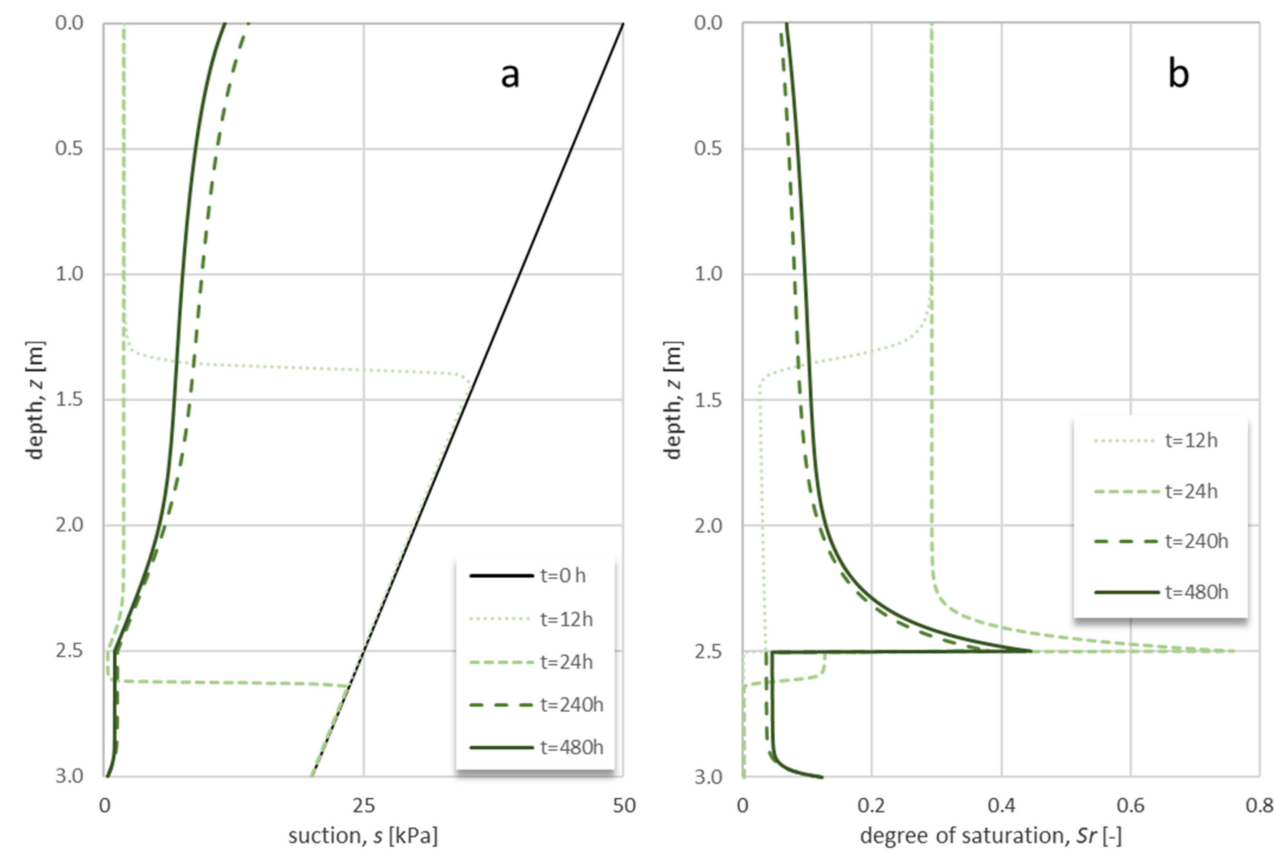

Figure 12. Infiltration process for a rainfall event with an intensity of $10 \mathrm{~mm} / \mathrm{h}$ and a duration of $24 \mathrm{~h}$ : (a) the suction profile, and (b) the degree of saturation profile.

\subsection{Stability Analyses}

This section refers to the results obtained from a numerical example of application, which was aimed at highlighting the hydraulic effects on slope stability conditions following a rainfall event lasting $24 \mathrm{~h}$ and at an intensity equal to $5 \mathrm{~mm} / \mathrm{h}$ and $10 \mathrm{~mm} / \mathrm{h}$, respectively. The case study is a slope (slope angle $\left.\alpha=36^{\circ}\right)$ of black scoriae layer $\left(\varphi=35^{\circ}\right.$, $\left.\mathrm{c}^{\prime}=0, \gamma=15 \mathrm{kN} / \mathrm{m}^{3}\right) 2.5 \mathrm{~m}$ thick superposed to a bottom layer of grey pumices $\left(\varphi=37^{\circ}\right.$, $\left.c^{\prime}=0, \gamma=12.4 \mathrm{kN} / \mathrm{m}^{3}\right) 0.5 \mathrm{~m}$ thick. The shear strength parameters of the two layers have been deduced by [5] and [40]. The water table is located at a depth of $z_{W}=5 \mathrm{~m}$ from the ground table. The profiles of the saturation degree and soil suction during the infiltration events are shown in Figure 7, Figure 9, and Figure 10 at different times of observation $(\mathrm{t}=12 \mathrm{~h}, 24 \mathrm{~h}, 240 \mathrm{~h}$, and $480 \mathrm{~h}$ ). These profiles, in turn, made it possible to estimate the soil shear strength at increasing depths, by adopting the failure criterion for unsaturated cohesionless soils proposed by Vanapalli et al. [41]. This leads to Equation (3), below:

$$
\mathrm{SF}(\mathrm{z})=\frac{\tau_{f}}{\tau}=\left(1+\frac{S_{r}(z) \cdot s(z)}{\gamma z \cos ^{2} \alpha}\right) \cdot \frac{\tan \varphi}{\tan \alpha}
$$

The decrease in the safety factor with depth, as the infiltration front proceeds, has been shown in Figure 13 as a consequence of the reduction in the positive contribution provided by the degree of saturation and suction in the expression (3). For a slope inclination close to the value of the internal friction angle of the shallow layer, it can be observed that for a rainfall event with an intensity (i) of $5 \mathrm{~mm} / \mathrm{h}$ and a duration of $24 \mathrm{~h}$, the factor of safety is progressively reduced as the infiltration front proceeds, but no instability of the slope occurs. At longer observation times, when the front reaches the interface between black scoriae and grey pumices, the formation of the capillary barrier (as described in Section 5.1 and shown in Figure 10) favors the further reduction in the safety factor-down to the instability condition-which is evident for the observation times of $240 \mathrm{~h}$ and $480 \mathrm{~h}$. The failure surface is localized within the black scoriae layer, while the underlying grey pumices layer remains stable $\left(\mathrm{SF}_{\min }=1.07\right)$. 


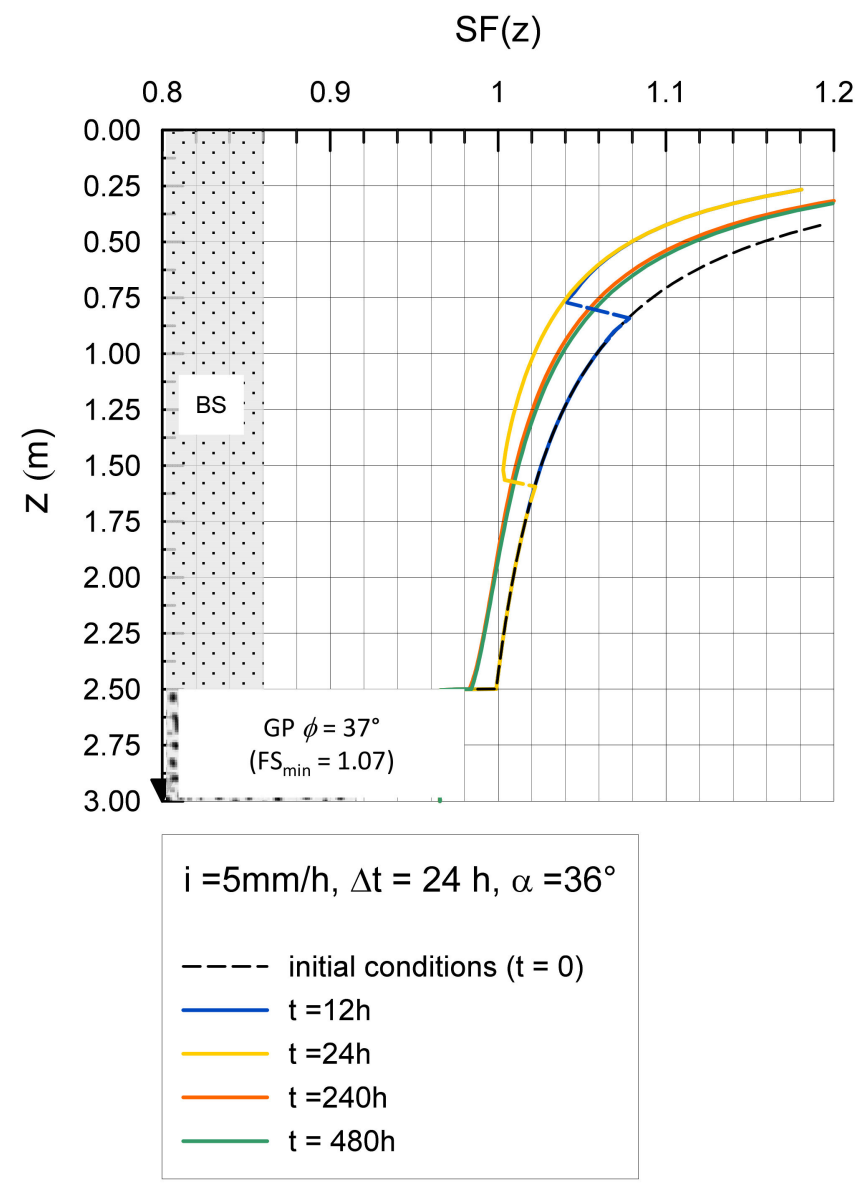

Figure 13. Safety factor (SF) vs. depth (z) for a rainfall event with an intensity (i) of $5 \mathrm{~mm} / \mathrm{h}$ and a duration of $24 \mathrm{~h}$, at increasing observation times.

For a rainfall event at a higher intensity $(i=10 \mathrm{~mm} / \mathrm{h})$ and a duration of $24 \mathrm{~h}$, the infiltration front reaches the interface during the rainfall event, and the formation of the capillary barrier favors the onset of the unstable condition during the $24 \mathrm{~h}$ of a rainfall event.

A stability analysis of the infinite slope model (for stability conditions close to failure) showed how the formation and permanence of the capillary barrier can induce the instability of the shallow layer, confirming the in situ observation of the localization of instabilities in the shallow finer layers. The failure condition is triggered by rainfall events at intensity and duration levels favoring water storage in the upper layer and minimizing the beneficial contribution of suction to the stability of the slope.

\section{Conclusions}

A detailed field survey allowed for the identification of a series of recent landslides, mainly located in the "Conca Napoletana" (Campanian plain), involving the SommaVesuvius pyroclastic deposits. The failure surface has been identified at the interface between grey pumice and black scoriae layers, likely due to the contrasting hydraulic properties between these two levels, which promote the formation of capillary barriers. This hypothesis has been explored in the present paper by means of a numerical study of water infiltration, parametrically simulated considering rainfall events of increasing intensity and duration. The numerical analyses showed the effects of progressive water storage in the upper, finer-grained layer of black scoriae, which can give place to the capillary barrier at the interface with the coarser-grained layer of grey pumices. The time history of the infiltration process allowed the present analyses to highlight the capillary barrier water break-through as a consequence of progressive suction equalization between the two layers, as well as the gravity-driven downward flux of water over time. The impact 
of infiltration, and the influence of the capillary barrier on the layers' stability, has been evaluated with reference to the unsaturated infinite slope model. The attainment of failure conditions of the black scoriae layer for a medium intensity, long duration rainfall event is consistent with the field observations.

Author Contributions: Conceptualization and methodology, M.C., G.R., D.C., L.P. and D.D.M.; investigation, C.S.; data curation, C.S., R.S., L.P. and E.V.; writing-original draft preparation, G.R. and M.C.; writing-review and editing, D.C., D.D.M., L.P., R.S. and E.V.; supervision, M.C., G.R. All authors have read and agreed to the published version of the manuscript.

Funding: This research received no external funding.

Conflicts of Interest: The authors declare no conflict of interest.

\section{References}

1. Khire, M.V.; Benson, C.H.; Bosscher, P.J. Capillary barriers: Design variables and water balance. J. Geotech. Geoenviron. Eng. 2000, 126, 695-708. [CrossRef]

2. Rahardjo, H.; Satyanaga, A.; Leong, E.C. Unsaturated soil mechanics for slope stabilization. In Proceedings of the 5th Asia-Pacific Conference on Unsaturated Soils, Pattaya, Thailand, 29 February-2 March 2012; pp. 103-117.

3. Pappalardo, L.; Piochi, M.; Mastrolorenzo, G. The 3550 YR BP-1944 AD magma-plumbing system of Somma-Vesuvius: Constraints on its behavior and present state through a review of Sr-Nd isotope data. Ann. Geophys. 2004, 47, 1471-1483.

4. Pappalardo, L.; Mastrolorenzo, G. Short residence times for alkaline Vesuvius magmas in a multi-depth supply system: Evidence from geochemical and textural studies. Earth Planet. Sci. Lett. 2010, 296, 133-143. [CrossRef]

5. De Vita, P.; Napolitano, E.; Godt, J.W.; Baum, R.L. Deterministic estimation of hydrological thresholds for shallow landslide initiation and slope stability models: Case study from the Somma-Vesuvius area of southern Italy. Landslides 2013, 10, 713-728. [CrossRef]

6. Cascini, L.; Sorbino, G.; Cuomo, S.; Ferlisi, S. Seasonal effects of rainfall on the shallow pyroclastic deposits of the Campania region (southern Italy). Landslides 2014, 11, 779-792. [CrossRef]

7. Urciuoli, G.; Pirone, M.; Comegna, L.; Picarelli, L. Long-term investigations on the pore pressure regime in saturated and unsaturated sloping soils. Eng. Geol. 2016, 212, 98-119. [CrossRef]

8. Picarelli, L.; Olivares, L.; Damiano, E.; Darban, R.; Santo, A. The effects of extreme precipitations on landslide hazard in the pyroclastic deposits of Campania Region: A review. Landslides 2020, 17, 2343-2358. [CrossRef]

9. Shackelford, C.D.; Chang, C.-K.; Chiu, T.-F. The capillary barrier effect in unsaturated flow through soil barriers. In Proceedings of the First International Congress on Environmental Geotechnics, Edmonton, AB, Canada, 10-15 July 1994; pp. 789-793.

10. Mancarella, D.; Doglioni, A.; Simeone, V. On capillary barrier effects and debris slide triggering in unsaturated soil covers. Eng. Geol. 2012, 147-148, 14-27. [CrossRef]

11. Damiano, E. Effects of layering on triggering mechanisms of rainfall-induced landslides in unsaturated pyroclastic granular soils. Can. Geotech. J. 2018, 56, 1278-1290. [CrossRef]

12. Crosta, G.B.; Negro, P.D. Observations and modelling of soil slip-debris flow initiation processes in pyroclastic deposits: The Sarno 1998 event. Nat. Hazards Earth Syst. Sci. 2003, 3, 53-69. [CrossRef]

13. Vingiani, S.; Mele, G.; De Mascellis, R.; Terribile, F.; Basile, A. Volcanic soils and landslides: A case study of the island of Ischia (southern Italy) and its relationship with other Campania events. Solid Earth 2015, 6, 783-797. [CrossRef]

14. Reder, A.; Pagano, L.; Picarelli, L.; Rianna, G. The role of the lowermost boundary conditions in the hydrological response of shallow sloping covers. Landslides 2017, 14, 861-873. [CrossRef]

15. Yang, H.; Rahardjo, H.; Leong, E.C.; Fredlund, D.G. A study of infiltration on three sand capillary barriers. Can. Geotech. J. 2004. [CrossRef]

16. Sharma, R.H.; Nakagawa, H. Numerical model and flume experiments of single- and two-layered hillslope flow related to slope failure. Landslides 2010, 7, 425-432. [CrossRef]

17. Mancarella, D.; Simeone, V. Capillary barrier effects in unsaturated layered soils, with special reference to the pyroclastic veneer of the Pizzo d'Alvano, Campania (Italy). Bull. Eng. Geol. Environ. 2011, 71, 791-801. [CrossRef]

18. Pagano, L.; Reder, A.; Rianna, G. Experiments to Investigate the Hydrological Behaviour of Volcanic Covers. Procedia Earth Planet. Sci. 2014, 9, 14-22. [CrossRef]

19. Tan, S.H.; Wong, S.W.; Chin, D.J.; Lee, M.L.; Ong, Y.H.; Chong, S.Y.; Kassim, A. Soil column infiltration tests on biomediated capillary barrier systems for mitigating rainfall-induced landslides. Environ. Earth Sci. 2018, 77, 589. [CrossRef]

20. Oldenburg, C.M.; Pruess, K. On Numerical Modeling of Capillary Barriers. Water Resour. Res. 1993, 29, 1045-1056. [CrossRef]

21. Stormont, J.C.; Morris, C.E. Method to Estimate Water Storage Capacity of Capillary Barriers. J. Geotech. Geoenviron. Eng. 1998, 124, 297-302. [CrossRef]

22. Rahardjo, H.; Tami, D.; Leong, E.C. Effectiveness of sloping capillary barriers under high precipitation rates. In Proceedings of the 2nd International Conference on Problematic Soils, Selangor, Malaysia, 3-5 December 2006; pp. 39-54. 
23. Scarfone, R.; Wheeler, S.J.; Lloret-Cabot, M. A hysteretic hydraulic constitutive model for unsaturated soils and application to capillary barrier systems. Géoméch. Energy Environ. 2020. [CrossRef]

24. Scarfone, R.; Wheeler, S.J.; Lloret-Cabot, M. Conceptual Hydraulic Conductivity Model for Unsaturated Soils at Low Degree of Saturation and Its Application to the Study of Capillary Barrier Systems. J. Geotech. Geoenviron. Eng. 2020, 146, 04020106. [CrossRef]

25. Santacroce, R.; Cioni, R.; Marianelli, P.; Sbrana, A.; Sulpizio, R.; Zanchetta, G.; Donahue, D.J.; Joron, J.L. Age and whole rock-glass compositions of proximal pyroclastics from the major explosive eruptions of Somma-Vesuvius: A review as a tool for distal tephrostratigraphy. J. Volcanol. Geotherm. Res. 2008, 177, 1-18. [CrossRef]

26. Sepe, C.; Calcaterra, D.; Di Martire, D.; Ramondini, M.; Russo, G.; Vitale, E.; Pappalardo, L. Role of capillary barriers in landslide susceptibility assessment in pyroclastic soils: Microstructure investigation and numerical analysis. Environ. Earth Sci. 2021, unpublished.

27. De Vita, P.; Di Clemente, E.; Rolandi, M.; Celico, P. Engineering geological models of the initial landslides occurred on april 30 2006, at the Mount of Vezzi (Ischia island, Italy). Ital. J. Eng. Geol. Environ. 2007, 2, 119-141.

28. Cruden, D.M.; Varnes, D.J. Landslide types and processes. In Landslides: Investigation and Mitigation; Turner, A.K., Schuster, R.L., Eds.; Transportation Research Board Special Report 247, National Research Council; National Academy Press: Washington, DC, USA, 1996; pp. 36-75.

29. Bertagnini, A.; Landi, P.; Rosi, M.; Vigliargio, A. The Pomici di Base plinian eruption of Somma-Vesuvius. J. Volcanol. Geotherm. Res. 1998, 83, 219-239. [CrossRef]

30. Pappalardo, L.; Buono, G.; Fanara, S.; Petrosino, P. Combining textural and geochemical investigations to explore the dynamics of magma ascent during Plinian eruptions: A Somma-Vesuvius volcano (Italy) case study. Contrib. Miner. Pet. 2018, $173,61$. [CrossRef]

31. Buono, G.; Pappalardo, L.; Harris, C.; Edwards, B.R.; Petrosino, P. Magmatic stoping during the caldera-forming Pomici di Base eruption (Somma-Vesuvius, Italy) as a fuel of eruption explosivity. Lithos 2020, 370, 105628. [CrossRef]

32. Arya, L.M.; Paris, J.F. A physicoempirical model to predict the soil moisture characteristic from particle size. Soil Sci. Soc. Am. J. 1981, 45, 1023-1030. [CrossRef]

33. Cecconi, M.; Vecchietti, A.; Pane, V.; Russo, G.; Cencetti, C. Geotechnical Aspects in the Assessment of Stability Conditions of the Volumni Hypogeum in Perugia. In Geotechnical Research for Land Protection and Development, CNRIG 2019; Calvetti, F., Cotecchia, F., Galli, A., Jommi, C., Eds.; Lecture Notes in Civil Engineering 2020; Springer: Berlin/Heisenberg, Germany, 2020 ; Volume 40.

34. Cecconi, M.; Cambi, C.; Carrisi, S.; Deneele, D.; Vitale, E.; Russo, G. Sustainable Improvement of Zeolitic Pyroclastic Soils for the Preservation of Historical Sites. Appl. Sci. 2020, 10, 899. [CrossRef]

35. Van Genuchten, M.T. A closed-form equation for predicting the hydraulic conductivity of unsaturated soils. Soil Sci. Soc. Am. J. 1980, 44, 892-898. [CrossRef]

36. Olivella, S.; Carrera, J.; Gens, A.; Alonso, E.E. Non isothermal multiphase flow of brine and gas through saline media. Transp. Porous Media 1994, 15, 271-293. [CrossRef]

37. Olivella, S.; Gens, A.; Carrera, J.; Alonso, E.E. Numerical formulation for a simulator (CODE_BRIGHT) for the coupled analysis of saline media. Eng. Comput. 1996, 13, 87-112. [CrossRef]

38. Mualem, Y. A new model for predicting the hydraulic conductivity of unsaturated porous media. Water Resour. Res. 1976, 12, 513-522. [CrossRef]

39. Lu, N.; Likos, W.J. Unsaturated Soil Mechanics; Wiley: New York, NY, USA, 2004; ISBN 978-0-471-44731-3.

40. Bilotta, E.; Cascini, L.; Foresta, V.; Sorbinow, G. Geotechnical characterisation of pyroclastic soils involved in huge flowslides. Geotech. Geol. Eng. 2005, 23, 365-402. [CrossRef]

41. Vanapalli, S.K.; Fredlund, D.G.; Pufahl, D.E.; Clifton, A.W. Model for the prediction of shear strength with respect to soil suction. Can. Geotech. J. 1996, 33, 379-392. [CrossRef] 